\title{
Study of the Legend of Holy Grail's Knight and Emperor Friedrich II by the European House of Andechs Meranien. From the Viewpoint Their Aim for Ending of International Religious War "the Crusades" in 12-13th Century
}

\author{
Takao Kawanishi \\ Doctoral Course, Kwansei Gakuin University, Japan \\ E-mail: takao.kawanishi@kwansei.ac.jp
}

\author{
Doi:10.5901/mjss.2013.v4n10p160
}

\begin{abstract}
In 12-13th Century, the Legend of Holy Grail's Knight in Europe such as Perceval in France and Parzival in Holy Roman Empire were appeared and spread. Since then they were known only the Chivalry story in Europe, not so related in international situation at the time like "the Crusades". However, my viewpoint stands that those stories of Legend were very close and strong influenced by Crusader Battle Situation and Movement on Knights of Crusade from Europe to Middle East, Africa, Asia as real history. In the same Century, one of the famous European House of Andechs Meranien ruled important Crusader's routes and key-areas having root of the Grail Knight's story in Europe. Finally, I wish to point out that House of Andechs Meranien conducted and supported Holy Roman Emperor Friedrich II as the ideal "Holy Grail's King" whose ability and spirit was very multicultural and global under mutual prosperity and peace beyond the dogma of Crusades as antagonism toward religion. Therefore, he could enter peacefully in Jerusalem as King like Legend of Holy Grail's Knight.
\end{abstract}

Keywords: Legend of Holy Grail's Knight, Crusader, House of Andechs Meranien, Emperor Friedrich II, Holy Roman Empire

\section{Introduction}

In 12-13th Century, the Legend of Holy Grail's Knight in Europe such as Perceval ou le Conte du Graal of C.Troyes(1140-end of 12c.) in France and Parzival of W.Eschenbach(1160or80-approx.1220) in Germany (Holy Roman Empire) were appeared and spread. Since then they were known only the Chivalry story with adventure and love in Europe, not so related in international situation at the time like "the Crusades".

However, my viewpoint stands that those stories of Legend were very close and strong influenced by Crusader Battle Situation and Movement on Knights of Crusade from Europe to Middle East, Africa and Asia as real history.

Moreover, in the same Century, one of the famous European House of Andechs Meranien ruled important Crusader's routes and key-areas having root of the Grail Knight's story in Europe, such as Franken in Germany including Bayreuth, Bamberg, and Ansbach near birth and vital place of W.Eschenbach, and Adriatic Seacoast including Dalmatia(around Slovenia and Croatia), and road to Verona in Italy across the Brenner Pass in Austria, and Bourgogne (Brugund) in France near the place of C.Troyes and so on. Then, the House managed access-routes from Bishopric Bamberg to Jerusalem and another Middle East's cities, and to Italy, France, Hungary, etc. This House is not known nowadays for extinction. But my view is that House of Andechs Meranien had new ideal beyond religional intolerance such as Crusade War.

In addition, this House had strong tie of the Staufer, and deeply understanding of the the Legend of Holy Grail's Knight. It means that this House connected between the Holy Roman Emperor of Staufer like Friedrich II (1194-1250) and the Legend.

As far as prior research about relationship between these works(Perceval, Parzival) and Holy Roman Emperor Friedrich II, it remain a few view point of literature,thus, historical and geographical or cultural-exchange approach is nothing. About Friedrich II, by earlier literatures such as historian E.H. Kantorowicz(1895-1963) and J. Burckhardt(181897), They watched Friedrich II 's talent and new idea depend on only himself like genius. In addition, his idea and characteristic was like Caesar of the Roman Emperor as great dictator with powerful army from Europe to Mediterranean area.

However, I wish to point out that House of Andechs Meranien conducted and supported Emperor Friedrich II as the ideal "Holy Grail's King" whose ability and spirit was very multicultural and global under mutual prosperity and peace beyond the dogma of Crusades as antagonism toward religion. Therefore, he could enter peacefully in Jerusalem as 
King like Legend of Holy Grail's Knight. So, at first, we go back to the time of $12^{\text {th }}$ century as the Birth time of Legend of Holy Grail's Knight stories.

\section{Legend of Holy Grail's Knight stories of $12^{\text {th }}$ Century and its alteration}

\section{1 "Incomplete" Perceval and its background on historical approach}

The origin and root of Legend of Holy Grail's Knight is various view, the present, it also try to seek another European country. So, in this chapter, it has researched about "incomplete" Perceval (ca.1181-91) by C.Troyes in France and Parzival (until ca.1204) by W.Eschenbach Germany (the Holy Roman Empire).

First written story about Legend of Holy Grail's Knight appeared as this Perceval by C.Troyes using partially another European Legends such as the following.

Perceval was influenced "Legend of King Authur" that finally completed story in $15^{\text {th }}$ century. This Authur's Legend had a root of "Historia Regum Britanniae"(1135) by G. Monmouth with Latin in England, about 20 years after, this was published and went to France, Historia Regum Britanniae was translated in old French language.

On the other hand, about story of Holy Grail's Legend used in the time of "the last supper" and received Christ blood in his crucified time, C.Troyes was influenced in "Joseph d'Arimathe" (end of 12c.) by Robert de Boron(-1212). He who was famous as most great Trouvère in the middle age of France was supported by Philip(1143-1191)Count of Flanders as patron. C. Troyes started to write Perceval under Philip's support.

It was said the reason Perceval was not complete was for C.Troyes's death, but his death year was not clear. In addition, his "Lancelot, the Knight of the Cart"(1170s) before Perceval was also incomplete why C. Troyes did not want to look down on Lancelot as knight of hero with loyalty and love in the end of story.

In this point of view, it can point out C.Troyes who highly believed chivalry and Christianity stopped and abandoned to complete Perceval by something reason before his death.

It was imagined that C.Troyes faced the historical situation abandoned to complete Perceval as Legend of Holy Grail's Knight admiring chivalry in Christianity of Europe.

About relationship between Perceval as Legend of Holy Grail's Knight and Crusader, from view point of difference fiction (Legend) and non-fiction (history), it was seemed that they were not related directly, or had indirectly a few relationships. However, I want to point out that Perceval and Parzival are directly related with Crusader history. I conclude that Crusader's movement and Battle situation is closely influenced to these stories of Legend of Holy Grail's Knight as following.

Philip of Flanders who was C.Troyes's patron participated in Crusader at Palestaine. C.Troyes who was fascinated Philip's activity and personality praised highly to him that he exceled King Alexsandor and Original of Perceval was given by him.

Philip of Flanders met King Jerusalem Baldwin IV(1161-85) in Jerusalem as Holy land. And the two tried together to battle of Montgisard(1177).

In this battle, Knights Templar(Templerorden) was one of Crusader Knights greatly contributed to the victory of Christian-side. By this win, prestige of Knights Templar was reached the peak in Christian-side of Europe because several hundred knights defeated miraculously more than ten thousands Islamic knights (army).

At that time, Knights Templar became their existence compared with European King's Army because the Knights fought for Crusader Battle with the Army such as Philip II of France (1165-1223) and Richard I as known Lion Heart King of England (1157-99). In this glorious time of Knights Templar, Perceval as Legend of Holy Grail's Knight began to be written by C.Troyes.

Also, Troyes at Champagne in France as known C.Troyes was closely related (born or active) place where was also important place of Hugues de Payens(1070-1136) who founded Knights Templar. Moreover, in 1129, Troyes at Champagne it was held historical congress admitted officially Knights Templar as Catholic monastic order. These facts strongly point out the possibility that Knights Templar was real model of Legend of Holy Grail's Knight.

On the other hand, Thierry of Alsace (1099-1168) was father of Philip of Flanders also participated in the second Crusader. When he went back from palestine to Bruges brought the sacred blood of Christ collected by the above mentioned Joseph d'Arimathe.

After that, Thierry of Alsace built Basilica style church that dedicated the sacred blood of Christ in this church. Thus, in order to write the great works of his father, it seem that Philipe demanded C.Troyes to write about Thierry's sacred blood of Christ as Holy Gral in Perceval's story. 
Moreover, C.Troyes said about Philip of Flanders who was honest and pure man when he heard slander of another man became so sad, and he loved justice, loyality and holy church, and first of all Troyes said he was given original story of Perceval by Philip himself. Thus, these mean that real model of Perceval was Philip of Flanders.

Above mentioned, Perceval was influenced not only Legend of King Arthur but also personality of Philip of Flanders who participated with Crusader that he went to Holy land of Jerusalem and another Arabic land, in addition, experience of Thierry of Alsace as Philip's father equal to find Holy Grail as blood of Christ.

Moreover, it existed that model of wounded King called Fisher King who hardly waited for Holy Grail's Knight. The Fischer King was exactly Baldwin IV, King of Jerusalem at that time.

He who had both excellent of talents and perfect looks was enthroned King of Jerusalem only 13 years old. However, he who got incurable disease became weak gradually, died at the early age of 24 years old for total paralysis.

In spite of this tragedy of younger King, his noble personality and decision making of politics shown in Jerusalem on holy land praised by historian in future years.

This meeting with King Baldwin IV seriously impacted to "Pure" Philip. The scene was reproduced as scene of Perceval "asking" to fisher King.

When Philip first entered to Jerusalem as "Holy Grail castle" met Baldwin IV, Philip could not say anything (asking) by heavy surprise to see miserable this King, and it can read from Perceval story that Philip deeply regretted that he could not cure and heal the King by his asking.

After King Baldwin IV's death, situations of Jerusalem and cities occupied Crusader in the Middle East changed completely by offensive movement of Islam.

In 1187 Crusader was completely defeated in historical battle of Hattin by Islam Army leading Saladin (1137-93). Caused lose of this battle, not only Kingdom of Jerusalem but also most of cities occupied Crusader had fallen after prosperity of one century.

Moreover, by this battle it fell completely prestige of Crusader justified as God's will before by those reasons that it was captured not only Crusader Knights commanders include Templer close relation to place of C.Troyes, and European feudal lords participated in Crusader, but also Jerusalem King Guy Lusignan(1159-94). Moreover, when it was exposed atrocities by Crusader that executed in their occupied land, the prestige of Crusader justified as God's Will was completely broken and fallen.

Because such dishonorable und misery situation was spread around Europe, C.Troyes no longer could write story of Ideal world of Knights of Christianity as Holy Grail's Knight, He gave up writing after his distress at the same situation of "Lancelot, the Knight of the Cart".

Also, Philip of Flanders who was patron of C.Troyes and model of Perceval had been death in battle of the third Crusader in 1191. It brought serious doubt and despair for C. Troyes to Ideal world of Jerusalem as Holy and God land of Crusader by these reasons of historical crushing defeat of battle of Hattin, inhuman massacre and plunder by Crusader, tragedy of Baldwin IV, and death of Philip of Flanders.

This "incomplete" story of Perceval ou le Conte du Graal by C.Troyes in France took over and completed as Parzival by W.Eschenbach in Germany with new vision and expansion.

\subsection{Completion of Parzival and its historical point of view}

W.Eschenbach known as the author of Parzival was said that he was born in area of Ansbach in middle of Franken in Germany, lived in the same time with C.Troyes, understood old French language, was Minnesänger admired chivalry as well as C.Troyes as Trouvère.

W.Eschenbach who was also known great poet in the middle age of Germany, served count of Thüringen, participated in "Sängerkrieg auf Wartburg( Sing-fight at Wartburg" (1207) was active in Franken area locating Bayreuth.

He pointed out in his Parzival's final chapter that Troyes did not convey correctly Legend of Holy Grail's Knight. Moreover, W.Eschenbach wrote in Parzival that he was completed the correct story and its conclusion under his land. In other words, he insisted that "incomplete Perceval" was completed by his Parzival in Germany.

Thus, Parzival revises Perceval and adds it to new expansion. But, Parzival first and last chapter are original of W.Eschenbach. Both chapters are appeared remarkably his ideal world.

At first, in the chapter 1 as Parzival opening that this place became in Islam area at that time such as Middle East, Africa, Spain etc. The Christianity of Legend of Holy Grail's Knight became light and weak. So, Parzival strengthen color of Islam in contrast to Perceval.

This introduction appears father of Parzival named Gahmuret who longed for East world, went to Baghdad in Iraq, 
served to calif as Islamic king who ruled two-thirds in the world.

So, Gahmuret went to land of Africa, married with Black colored Queen, and ruled her country.

About this Queen, W.Eschenbach admired highly her Minne that she was a heathen and different race for him, and that she had so sincere and womanly mind that he never heard before. He continues that her purity of heart and fallen tear looks like sacred baptism.

Moreover, the active location of Parzival spread mainly in Islam area such as Cairo, Alexandria, Morocco, Damascus and Persia etc. W.Eschenbach got information about Crusader and Islam world in that time by Guiot de Provins (-1208) from Champagne. Guiot participated in the $3^{\text {rd }}$ and $4^{\text {th }}$ Crusader because he went to trip around Europe and the East.

Next point, Holy Grail (grâl) itself was changed holy "stone" from grail of Christianity to new interpretation, for example to Black stone Kaaba of Holy place in Islam or wiseman's stone in Solemon of Judaism.

Moreover, in Parzival it was clearly divided roles between "a fool" as the first concern and "a wise" as supporting and advising. Therefore, it became more closely Parsifal as "Pure fool" that Richard Wagner(1813-83) changed the name from Parzival to Parsifal in his Opera.

In the last chapter, Parzival as a fool was spiritually awaken and attained enlightenment through various experience and ordeal as Holy Grail's Knight. Finally, Parzival was invited Holy Grail's Castle and succeeded to the King of Holy Grail. In the story of Parzival, succession of throne by Parzival meant as Savior not only world of Christianity but also other religious world.

Such as Parzival by W.Eschenbach had also same viewpoint of Perceval by C.Troyes between fall of Crusader from European side and raise of Islam form Middle Eastern and Asian side.

The remarkable activity and personality of Gahmuret in Parzival was very close to Islamic Hero of Saladin who had superior battle plan and was praised from Crusader Knights as enemy to release most of Crusader's captive with his merci. Moreover, the active place of Gahmuret is same of Saladin's its place. Thus, it must be noteworthy that W.Eschenbach used image of Saladin as Islamic Hero to the father of Parzival.

As for W.Eschenbach, center of the world is not Europe of Christianity but the East world having various ideas, religions, and wealthy and fascinating culture. In Parzival, castle of Holy Grail was in Monsalvat where showed religionus color between Christianity and Islam.

After that, Wagner in Parsifal who set Monsalvat for Montserrat, where was holy place of Catalonia in Spain had religionus diversity, and appeared in Legend of Arthur. It can say that the 3 authors, C.Troyes, W.Eschenbach, and Wagner have same viewpoint and mind over centuries.

On the other hand, above mentioned, W.Eschenbach also has a viewpoint of "12th Century Renaissance" such as European society influenced by Islamic and Eastern culture, and compassion(Mitleid) of same value of the world such as Global view called "Cosmopolitanism".

So, the next chapter studies relation of Legend of Holy Grail's Knight and House of Andechs Meranien in the Holy Roman Empire.

\section{House of Andechs Meranien and Legend of Holy Grail's Knight}

\subsection{Relation among Andechs Meranien and Crusader Knights, and Legend of Holy Grail's Knight}

This House of Andechs Meranien was famous nobles (Adelsgeschlecht) around Europe (the Holy Roman Empire) appeared in $11^{\text {th }}$ Century, prospered in $12^{\text {th }}$ until the first half of $13^{\text {th }}$ century. It was formed alliance that Count of Andechs (Grafen von Andechs) and Duke of Meranien (Herzogtum Meranien) was unified by marriage each other.

House of Andechs originated around lake Ammer and Sturnberg in south of Bayern near the Alps, had Castle in Innsburk, and spread ruling area by marriage with influential House of feudal lord called marriage-politics (Heiratspolitik).

Thus, House of Andechs Meranien ruled most of Bayern including Bishopric Bamberg, Bayreuth, Bourgogne(Brugund at that time) in France, road to Verona in Italy across the Brenner Pass in Austria. Moreover, ruled sea routes on Adriatic Seacoast including Dalmatia(around Slovenia and Croatia) this House kept trade routes from Kingdom of Jerusalem and Palestine City that Crusader kept, until Bishopric Bamberg that was core in the Holy Roman Empire at the time.

This route of House of Andechs Meranien that connected both Holy places became place of important connecting Crusader's cities in Middle East and main cities in Europe by keeping in close contact with Crusader Knights following.

Moreover, the routes of House of Andechs Meranien that spread in the center of Europe were deeply related with 
Legend of Holy Grail's Knight. This reason of relation ruling place of this House was influenced around Champagne of C.Troyes and Ansbach of W.Eschenbach. Through trading of both place, for example books of Perceval by C.Troyes entered to Ansbach in House of Andechs Meranien's territory. In addition, this House made for them about one of the Legend of Holy Grail's Knight named Wigalois by Wirint von Gafenberg, and that this Wigalois story was inflienced in Parzival of W.Eschenbach.

Moreover, through trading territory and route of House of Andechs Meranien, such as treasures and necessities, and culture was brought to around Bishopric Bamberg, near side was from France and Italy, far place was from Jerusalem, Byzantine and Asia and Africa. For example, treasures of House of Andechs Maranien had Golden dress for Mass made by Islam worker from the East, the Weil of St. Maria as sacred relic and the Wiltener Kelch like the Grail's treasure engraved about Christianity in $12^{\text {th }}$ century "the Crusades" by Andechs Meranien from the East to Tirol region in Austria of their one of mainlands, etc.

This House, as showed queen of Poland Jadwiga Śląska, Hedwig von Andechs (1174-1243) sent to be married their daughters to another European Noble House. The queen sent to marry her daughters to Philip II (1165-1223) King of France, and Andrew II (1177-1235) King of Hungary. House of Andechs Meranien by means of this marriagepolitics tied alliance with European countries. Moreover, using power of these countries deeply connected with Bishopric and Crusader Knights, and that this House related closely trading with area of Kingdom of Jerusalem, Arabia, and Mediterranean Sea.

This Queen Jadwiga root of House of Andechs Meranien who rendered service to poor and week person was raised as Holy woman. She was adored by land-people and Crusader Knights who supported this service. On the other hand, she made closely cooperation with these Knights.

Also, this queen's daughter married in Count of Thüringen as patron of W.Eschenbach, after that, she was known as Saint Elisabeth (1207-31). For that reason she endeavored to help and protect poor person, she was expelled from Thüringen, and moved to Bamberg. W.Eschenbach also dedicated Song of Minne praised her.

After that, this Saint Elisabeth appeared as Heroin at the stage of Wagner's Opera named Tannhäuser und der Sängerkrieg auf Wartburg. On the other hand, She also made closely relationship with Crusader Knights who who supported this help through her leadership in church and hospital. For example, her brother-in-law named Konrad von Thüringen was the fifth Grand Master of the Teutonic Knights(Deutscher Orden). The Knights build Saint Elisabeth Church in Marburg where she was very active place.

On the other hand, House of Andechs Meranien gave their routes not only Teutonic Knights but also Knights Templer, for example, that sea routes from Jerusalem to Dalmatia via Adriatic Seacoast, and land routes from Dalmatia to Germany via Brenner Pass, or from Byzantine to Gemany via Hungary etc.

This House brought relic and merchandise from Arabic, Asia, and Africa to around Bishopric Bamberg, it is said Oberfranken region ruled by House of Andechs Meranien. One of the cities Coburg has wappen of Moore in nowadays meaning existence of Islamic cultue under the tolerance of this House. Also Bayreuth following became basement and staying place of this House and Crusader Knights. Also Crusader Knights after $13^{\text {th }}$ century turned the direction from Jerusalem of Middle East to Poland of east border of the Holy Roman Empire to protect against invasion of Mongolian Army. In Bayreuth, Crusader Knights movement increased the position as cross point of these Knights movement, trade to East-side and strategic base of military.

\subsection{Reconstruction of Bishopric Bamberg and House of Andechs Meranien - to the New Millennium Kingdom-}

On the one hand, House of Andechs Meranien spread territory and trading routes by marriage-politics, on the other this House tried to go into Bishopric Bamberg as Holy world, namely, "new Rome in above Alps".

This Bishopric Bamberg that was founded Bishopric at Bamberg in Millennium by Holy Roman Emperor Heinrich II (973-1024) aiming New Rome that Bamberg had 7 hills like Rome became center of the Holy Roman Empire at that time.

This Heinrich was canonized with his spouse Cunigunde (975-1040) deeply believed in God and Christianity, and the pair buried together inside Bamberg Dom(Cathedral).

After their death, Bishopric Bamberg produced Roman Catholic Pope Clement II (1005-47, as Pope 1046-47) who was first time "Pope of above Alps". After that, House of Andechs Meranien also drew following their Ideal of "the New Millennium Kingdom under Legend of Holy Grail's Knight".

House of Andecs Meranien donated hugely to this Bishopric and reconstructed Bamberg Dom that built four large steeples at the corner in 1211-37.

Also, In the inner sanctuary of this Dom with two Patron saints of this Dom who were St. Petros and St. 
Georg(Georgius) was put on new statue named Rider of Bamberg (Bamberger Reiter). This statue was deeply related with Legend of Holy Grail's Knight and Knights Templer that cooperated with House of Andechs Meranien at that time.

\section{Emperor Friedrich II and Andechs Meranien- seeking of New Idea of the World-}

\subsection{Andechs Meranien seeking new world system of the Holy Roman Empire}

These Andechs Meranien also supported the Staufer and the Holy Roman Empire. Staufer Heinrich VI.(1165-1197,King of Germany 1169-, Holy Roman Emperor 1191-,King of Sicily 1194-) was crowned King of Germany at Bamberg in 1169, at the age of four.

On the other hand, Berthold (- 1204) became the Count(Graf) of Andechs (as Berthold IV, 1172-) and first Duke(Herzog) of Merania (1183-), thus he was called Berthold IV of Andechs Meranien (Graf von Andechs and Herzog von Meranien) .

In 1186, Berthold IV accompanied the Emperor Heinrich VI to the Kingdom of Sicily. In 1189, Berthold IV led the third division of the imperial army and was its standard-bearer on the Third Crusade.

Berthold IV had to undergo the great Saladin and his Islamic Army, in addition, above mentioned, this House of Andechs Meranien was very close to the ideal world of Legend of Holy Grail's Knight like Parzival. So, After Heinrich Vl's death in 1197, Berthold IV and this House continued to support Staufer emperor to introduce the new world system in the Holy Roman Empire from center of the Mediterranean in Sicily to their Bamberg as place of the Legend of Holy Grail's Knight. And finally, Andechs Meranien and Staufer had and formed on the new ideal and generational man, he was Friedrich II.

\subsection{Emperor Friedrich II as Holy Grail's Knight}

Because Heinrich VI of the Staufer and Berthold IV of the Andechs Meranien sought to the new ideal successor of the Holy Roman Empire, It can say that the Heinrich VI's son Friedrich II needed the mysterious Legend from his birth until his end of life time as the new ideal man like new or reborn Christ and Parzival as the Legend of Holy Grail's Knight. And because Heinrich VI was dead when Friedrich II was 3 years old, Berthold IV of the Andechs Meranien supported to crown him as German King.

Moreover, Friedrich II himself had various talents and possibility called "stupor mundi" (the wonder of the world). Also he was called "the first modern man on the throne" by Burchhardt.

Friedrich II lived in Palelmo in Sicily using seven langage such as Latin, Greek and Arabic etc. His ability got so many cultue and religion, science not only from Europe but also Arabia, Africa, Asia in the world, moreover from this earth to universe reach to God as All Creator.

On the other hand, at this Palelmo in $19^{\text {th }}$ century, Parsifal of Wagner's Opera above mentioned finally completed. This meaning is that Wagner knew very well about Friedrich II by reading books, and that I intend Wagner thought one of Parsifal model was this Friedrich II of the Holy Roman Emperor in Palelmo.

\subsection{Entering to Juresalem as the King like Parzival}

In addition, He tried to make new world system as the Legend of Holy Grail's Knight. It is like Parzival story at the Church of the Holy Sepulchre in Jerusalem. This church place was said that Christ had been crucified, and he was pierced by spear (Holy Spear) and shed their blood (Holy Blood), finally, his blood was kept in the Holy Grail in the legend of Christianity.

In 1229, Friedrich II as Parzival and his Teutonic Knights as Grail's Knights entered in Jerusalem very peacefully not to use his forces, and He crowned as Juresalem King like Holy Grail's King at the Church of the Holy Sepulchre. At that time, it can say that he completely imaged final story of Parzival in the Legend of Holy Grail's Knight.

And in this moment, Friedrich II as the wonder of the world realized in peace of Jerusalem beyond more than one hundred Chirsitian and Islam world war situation Crusades. And this Friedrich II's work is not only world historical meaning of ending the War but also possibility of mutual understanding on human-being around the world to the future in nowadays. At the same time, the idea and dream of Andechs Meranien and the Stafer came true. 


\subsection{End of the Era - Staufen and Andechs Meranien -}

In spite of this Friedrich II and Andechs Meranien with the new idea to the world was not understood at that time, it is for several reason.following,

1) Friedrich II and this idea was strong againt Catholic Authority and Europiean Cathoric such as Guelphs and Haus Welfen.

2) And at that time by Crusedus, In Europe and Middle East, Asia, African region had serious religional-cutural misunderstanding and prejudice each other.

3) The Legend of Holy Grail's Knight like Parzival as the new peace theory in the world is not so spead to all Asian-area's civilian because of using Europian Langage and the hostility in the long war situation above mentioned.

4) About the reason 1) or 2), the House of Andechs Meranien was attacked by the Authorities like Welfen and become week and finally extincted. For example, at Bamberg in 1208 for Murder of Philipp von Schwaben (1178-1208), the House in Germany was attacked by this responsibility in their territory.At last this House was end in the middle of $13^{\text {th }}$ century, in the same time, Friedrich II and Stafer Dynasty in the Holy Roman Empire had finished.

However, in spite of persecution of them, the sprits and idea of Andechs Meranien and Friedrich II remained their land from Europe to the East, and succeeded to the House of Hapsburg, and that revived as Protestantism and Mystisism of Europe like the Legend of Holy Gail's Knight or Cosmopolitanism like Freemasonry until now.

\section{Conclusion - Legend of Holy Grail's Knight and Emperor Friedrich II in nowadays}

\subsection{Mind of House of Andechs Meranien and "Rider of Bamberg"}

In this thesis, from historical viewpoint about Legend of Holy Grail's Knight succeeding at Bayreuth in Germany, it considered about its succession and metamorphose of posterity.

In this paragraph at conclusion, it considers again about statue Rider of Bamberg (Bamberger Reiter) newly build House of Andechs Meranien when this House reconstructed Bamberg Dom putting whole their heart and soul.

This statue is said typical works in Bamberg Dom as landmark of the old city registered as World legacy by UNESCO nowadays. However, this rider's model is not clear, thus until now, it is not concerned about historical meaning of its making background and spirituality of Rider of Bamberg. The opinion about model of Bamberger Reiter exists the Holy Roman Emperor Philip(1178-1208) who was died in Bamberg, or St.Stephan I (969-1038) who was King of Hungary roots of Andechs Maranien. However, it is not clear reasons why this sculpture is innocent young man without arms until now.

However, I consider that this statue exactly expressed "Holy Grail's Knight" as Ideal sprit of House of Andechs Meranien. Though this statue is rider meaning of knight, do not have any arms such as sword and shield, moreover this knight have image of pastoral scenery such as youth of Franken countryside. I want to point out this statue man is Parsifal (Parzival at that time) as Holy Grail's Knight. And it suggests the Knight is Friedrich II in youth above mentioned.

Parsifal who do not know existence of Knight by his Mother hated War and Battle lived in countryside having nothing to do with Battle fields. Moreover, recently this status was restored to original using current science technology, as a result, it was cleared that this status was put on red clothes. In short, this red clothes means that Parsifal who saw Knight at first time and admired world of Knight and chivalry won the first duel with Knight and got his red clothes.

On the other hand, above mentioned, the face and expression of statue Rider of Bamberg (Bamberger Reiter) has not dignity to be such as completed Knight, but image of "Pure fool" like Parsifal becoming Holy Grail's Knight drawing by C.Troyes, W.Eschenbach, and Wagner. Moreover, head of this status put on crown, above the status decorated by king castle of Heaven such as Castle of Holy Grail, thus this can say exactly Parsifal becoming King of Holy Grail.

House of Andechs Meranien that has their dream such as New Millennium Kingdom in Bishopric Bamberg wanted real holy Kingdom as Heaven under good relationship by international exchange of culture and trading from diplomatic (nation) until personal (individual) aiming mutual understanding and cooperation from their tradition of peace diplomatic policy such as marriage politics and welfare works for poor and week people above mentioned than tyranny such as colonialism by military power called armed hegemonic diplomacy.

Above such ideal of House of Andechs Meranien was greatly influenced to Parzival of W.Eschenbach who was active in this House ruling area. And the symbolic ideal was remained as Bamberger Reiter meaning Holy Grail's Knight 
by this House for the future generations.

In Bamberg Dom the tomb of Kaiser Heinrich II and Cunigunde existed above mentioned. The pair do not have successor, but they had profound believing were raised both as Saint, and above at their tomb in Dom put on the Bamberger Reiter.

It exactly consist composition that the pair was given Parsifal as their son by the grace of God. In its behind, the altar of bishop is shined by dazzling stained glass. It can say that the inside of cathedral was reproduced miracle of Legend of Holy Grail's Knight by Andechs Meranien.

Moreover it expressed scene of great blessing coming New millennium Kingdom by the descent of God drawn in the ceiling. So, the next last chapter, I intend about possibility this Rider of Bamberg is Friedrich II as the Legend of Holy Grail's Knight.

\subsection{Emperor Friedrich II as Holy Grail's King in the World -Dream of Andechs Meranien for the ending of International religional Battle Situation-}

The new idea of the world of Friedrich II was finished with extinction of Andechs Meranien and fall of Staufer above mentioned. Moveover, by revive of the Catholic and Pope's supporters had been erased completely about the great Idea of Both Friedrich II and Andechs Meranien.

But in nowadays, we can trace it using academical approaches from the memento of Andechs Meranien like Bamberg Dom and the Rider.

In this last sentence, I want to mention one more memento of Freidlich II. It is his mysterious Castle named "Castel del Monte" in the Apulia region of southeast Italy. Untill now, It is said Castel del Monte is basement of his hunting or fortress of the Crusadus against heathen or enemy countries. However, it can not explain why he made this by unique geometric octagonal design. About this, it was said this octagonal Castle is similar to Dome of the Rock in Jerusalem.

I see it is important from viewpoint of the Legend of Holy Grail's Knight. Because this Dome of the Rock was not only religionous holy place in Islamic and Jewish but also headquarter of Knights Templer related with the Legend of Holy Grail's Knight. At that time, the Templer used this Dome as Holy Grail Castle. But the Knights lost graduately their power since Hattin Battle above mentioned. So, instead of the Templer, Teutonic Knights of the Holy Roman Empire increased the power by Fiedrich II. So, I wish to point out Castel del Monte was made by him as the New Holy Grail Castle in his era.

And I see that Fiedrich II wants to use this Holy Grail castle(Castel del Monte) with his supporters like Andechs Meranien and this Teutonic Knights as center of the new ideal world to go to another region with sprit of peace and cooperation like Middle-East, Africa and Asia by sea-road.

This Castle locate center of Mediterranean and the Globe at that time. And the new Grail Knights like Wigalois as a model of Berthold IV for leading and protecting around Friedrich II as Parzival go to search the new value and truth like Holy Grail around the world.

In addition, this unique geometric octagon was imaged not only Islamic or Jewish background but also Asian Buddism like Dharmacakra (Dharma wheel, Japanese: Hou-rin) or fortune-telling like Feng shui(Wind-water) using Chinese astronomy. Thus, this stupor mundi(Friedrich II) might get and use profound knowledges all over the world for the new generation.

In this myterious Castle, using such the world thoughts and Science of Astronomy, Astrology or Fantasy, Friedrich II felt deeply meditation and inspiration from global thinking to universal idea such as Creatur of the Universe beyond his body. And in this New Holy Grail Castle, he imaged the new idea of the world like peace and tolerance of cross-culture as a human-being of the Universe and Parzival as world-Legend of Holy Grail's King in new generation said the firstperson of Renaissance through nowadays on $21^{\text {st }}$ century.

\section{References}

Houben, H. (2008). Kaiser Friedrich II Herrscher, Mensch und Mythos. Stuttgart.

Kantorowicz, E.H. (2008). Kaiser Friedrich der Zweite. Stuttgart.

Burckhardt, J. (2009). Die Kultur der Renaissance in Italien. Stuttgart.

Uhhli, E. (2010). Die drei grossen Staufer: Friedrich I. Barbarossa - Heinrich VI - Friedrich II. Wiesbaden.

Oster, U.A. (2009). Die Frauen Kaiser Friedrichs II. München.

Chrétien de Troyes. (2009). Le Roman de Perceval ou Le Conte du Graal. Stuttgart.

Wolfram von Eschenbach. (2006). Parzival I, Parzival II. Frankfurt am Main. 
Wirnt von Grafenberg. (2005). Wigalois. Berlin.

Csampai, A.. u. Holland, D. (1984). Parsifal Texte,Materialien,Kommentare. Hamburg.

Frappier, J. (1979). Chrétien de Troyes et Le Mythe du Graal. Paris.

Hennig, L. (1998). Die Andechs Meranien in Franken. Europäisches Fürstentum im Hochmittelalter. Mainz.

Kirmeier, J. u. Brockhoff, E. (Hrsg). (1993). Herzöge und Heilige Das Geschlecht der Andechs Meranien im europäischen Hochmittelalter. München.

Weinfurter, S. (2002). Heinrich II. Herrscher am Ende der Zeiten. Regensburg.

Meyer, O. (1973). Oberfranken in Hochmittelalter Politik-Kultur-Gesellschaft. Bayreuth.

Trübsbach, R. (1993). Geschichte der Stadt Bayreuth. Bayreuth.

Arcovito, F. (2010) Castel del Monte. Un mistero svelato. Sicilia.

Götze, H. (1998). Castel del Monte. Geometric Marvel of the Middle Ages. London.

Kawanishi, T. (2011). Historical Studies about relationship between Legend of European Holy Grail's Knight and City of Bayreuth in Germany - from "Pereval" to "Parzival" , and "Parsifal" — Studies in Comparative Culture

(The Japan Association of Comparative Culture, No.99. pp. 25-46). Kyoto.

Kawanishi, T. (2008). Die Stadt Bayreuth und Richard Wagner. Germanistik Kyoto Nr.9 (Japanische Gesellschaft für Germanistik, Germanistenverband Kyoto) S.1 19, Kyoto. 